\title{
Analysing Co-creation and Co-production Initiatives for the Development of Age-friendly Strategies: Learning from the Three Capital Cities in the Basque Autonomous Region
} DOI:

10.1017/S1474746421000282

\section{Document Version}

Accepted author manuscript

Link to publication record in Manchester Research Explorer

Citation for published version (APA):

Zuniga, M., Buffel, T., \& Arrieta, F. (2021). Analysing Co-creation and Co-production Initiatives for the Development of Age-friendly Strategies: Learning from the Three Capital Cities in the Basque Autonomous Region. Social Policy and Society. https://doi.org/10.1017/S1474746421000282

Published in:

Social Policy and Society

\section{Citing this paper}

Please note that where the full-text provided on Manchester Research Explorer is the Author Accepted Manuscript or Proof version this may differ from the final Published version. If citing, it is advised that you check and use the publisher's definitive version.

\section{General rights}

Copyright and moral rights for the publications made accessible in the Research Explorer are retained by the authors and/or other copyright owners and it is a condition of accessing publications that users recognise and abide by the legal requirements associated with these rights.

\section{Takedown policy}

If you believe that this document breaches copyright please refer to the University of Manchester's Takedown Procedures [http://man.ac.uk/04Y6Bo] or contact uml.scholarlycommunications@manchester.ac.uk providing relevant details, so we can investigate your claim.

\section{OPEN ACCESS}




\section{Analysing Co-creation and Co-production Initiatives for the Development of Age-friendly Strategies: Learning from the Three Capital Cities in the Basque Autonomous Region}

Link to publication record in Manchester Research Explorer

Citation for published version (APA):

Zuniga, M., Buffel, T., \& Arrieta, F. (2021). Analysing Co-creation and Co-production Initiatives for the Development of Age-friendly Strategies: Learning from the Three Capital Cities in the Basque Autonomous Region. Social Policy and Society.

Published in:

Social Policy and Society

\section{Citing this paper}

Please note that where the full-text provided on Manchester Research Explorer is the Author Accepted Manuscript or Proof version this may differ from the final Published version. If citing, it is advised that you check and use the publisher's definitive version.

\section{General rights}

Copyright and moral rights for the publications made accessible in the Research Explorer are retained by the authors and/or other copyright owners and it is a condition of accessing publications that users recognise and abide by the legal requirements associated with these rights.

\section{Takedown policy}

If you believe that this document breaches copyright please refer to the University of Manchester's Takedown Procedures [http://man.ac.uk/04Y6Bo] or contact uml.scholarlycommunications@manchester.ac.uk providing relevant details, so we can investigate your claim.

\section{OPEN ACCESS}




\title{
Analysing Co-creation and Co-production Initiatives for the Development of Age-friendly Strategies: Learning from the Three Capital Cities in the Basque Autonomous Region
}

\author{
Martin Zuniga*, Tine Buffel** and Felix Arrieta*** \\ *Social Work and Sociology Department, University of Deusto, Bilbao, Spain \\ E-mail: martin.zuni@deusto.es (Contact author) \\ ${ }^{* *}$ School of Social Sciences, University of Manchester, Manchester, United Kingdom \\ E-mail: tine.buffe/@manchester.ac.uk \\ ***Social Work and Sociology Department, University of Deusto, Donostia/San Sebastian, Spain \\ E-mail: felix.arrieta@deusto.es
}

Driven by the ageing process taking place in the Basque Autonomous Region (BAR), the 'Age-Friendly Cities and Communities' (AFCC) initiative has become a major political reference for the development of ageing policies in the territory. This article addresses this subject by means of a qualitative study that analyses how the three main capital cities in the region are implementing age-friendly strategies, with a focus on co-creation and co-production processes. The article examines the challenges they are currently facing in the development of the aforementioned participatory processes. Our research suggests that political involvement, even if necessary, is meaningless if the strategy is not embedded in the work of influential stakeholders. Moreover, the success of communities in becoming more age friendly will, to a large extent, depend on whether older people, including those facing social exclusion, become involved as key actors in future research and policies around age-friendly developments.

Keywords: Age-Friendly, ageing, co-creation, co-production.

\section{Introduction}

The demographic transition which European societies are undergoing, characterised by the growth in numbers and proportion of people sixty-plus, has brought issues related to ageing and care to the centre of political debate at all institutional levels. From the local to the national level, public institutions are searching for new ways of organising welfare and care systems, with the aim of improving responses to the challenges presented by the recent demographic, political and economic changes (Pestoff, 2011). The 'Age-Friendly Cities and Communities' (AFCC) strategy proposed by the World Health Organization (WHO) has become a global reference for the development of ageing policies, and more inclusive cities, neighbourhoods and communities. In this field, BAR represents an interesting reference point for a case study, not only because it is the Spanish region with the highest number of cities that belong to the global network, but also because it has its own regional network, as well as many local initiatives in operation. 
One of the approaches proposed by the 'Age-Friendly' framework is to promote the role of neighbour and community relations, as well as the participation of older people in the design and development of policies in order to respond more adequately to the challenges at hand. In this respect, several studies have shown that the social environment has an important role in shaping older people's health and wellbeing (Kano et al., 2018), as older people living in less age-friendly communities have reported lower levels of wellbeing (Nieboer and Cramm, 2018).

One dimension to the age-friendly debate has been the influence of ideas relating to co-production and co-creation, (see, among others, Buffel, 2015, 2018a, 2018b; Buffel and Phillipson, 2016; Doran and Buffel, 2018; Moulaert and Garon, 2016; Zuniga et al., 2019). These concepts refer to the involvement of citizens in the design, management, implementation or evaluation of a certain policy or service. Such processes are developed on the basis that they have the capacity to make policies and practices more responsive to the needs and demands of the people involved. Despite the growing interest in this approach, there remains a need for experimentation in terms of testing and learning from participatory and collaborative approaches where older people are involved in those processes (Buffel and Phillipson, 2016).

In our article, this subject is examined by means of a qualitative study, analysing how three cities are implementing age-friendly strategies, with the focus being on co-creation and co-production initiatives. First, the WHO 'Age-Friendly' framework is presented, from a global perspective, in terms of its development in the analysed context. Secondly, co-creation and co-production are discussed as valuable tools for the development of age-friendly strategies. Thirdly, the Basque socio-political reality is described, as well as some of the key features of the region. Next, the methodology is presented, and the main findings obtained during the analysis are then presented. Finally, the last section presents the discussion about the challenges which have arisen concerning the participatory processes and the involvement of older people in the development of 'Age-Friendly' policies.

\section{A brief introduction into the 'Age-Friendly' initiative}

The 'Age-Friendly Cities and Communities' (AFCC) movement, and the 'Global Network of Age-Friendly Cities and Communities' (GNAFCC), are part of the World Health Organization's (WHO) agenda on ageing issues. Although Age Friendly Initiatives are usually aimed at people aged sixty-plus, they could be considered as a cross-disciplinary strategy. The starting point of the movement can be traced back to a research project carried out in 2006 in thirty-three cities around the world. This study was led by WHO and the Public Health Agency of Canada (PHAC) and focused on the advantages and barriers that older people experience in eight 'age-friendly' domains: housing, transport, information and communication, outdoor spaces and buildings, community support and health services, social participation, civic participation and employment, respect, and social inclusion (WHO, 2018).

Four years later, in 2010, the GNAFCC was launched, starting with eleven cities, and increasing up to around 1000 in $2019^{1}$. As Rémillard-Boilard (2018) has argued, the endorsement of this movement by the United Nations, WHO and the European Union has encouraged the development of a wide range of age-friendly policies and initiatives at local, national, and international levels. The age-friendly movement has also been influential in raising awareness about the need to prepare for a changing population, 
and major institutions and associations have incorporated this strategy into their work plans and organisational goals (Lawler, 2015). The AFCC movement has attracted a considerable level of interest, not only from political stakeholders but also within academia, with a growing number of studies providing an international comparative perspective (see among others, Buffel et al., 2018; Buffel and Phillipson, 2016; Kano et al., 2018; Moulaert and Garon, 2016). However, to date, there has been limited research focusing on the case of Spain and BAR in particular.

Moreover, further research is required in order to determine which aspects make AFCC strategies successful. Steels (2015) suggests that some of the key elements to examine are the following: multi-stakeholder collaborations, political involvement and financing or investment in the social environment, and especially, how a city can ensure that these interventions are sustainable.

\section{'Age-Friendly' movement in Spain}

In the case of Spain, IMSERSO (Spanish Institute for Older People and Social Services) has been the official partner of WHO for the development of age-friendly strategies since 2011. This public institution manages the national network of age-friendly cities in Spain, offering information and consultancy, and facilitating the dissemination or communication of local initiatives. In 2013, the 'Friendly Cities' working group was created, with representatives from national organisations and local authorities. This working group was responsible for developing and disseminating age-friendly strategies in Spain. According to data provided by IMSERSO $\left(2019^{2}, 167\right.$ cities are part of the national network, thirty-five of which are located in BAR - the region with the highest number of cities that are a part of the network, followed by Catalonia with twenty-one.

\section{'Age-Friendly' movement in the Basque Autonomous Region}

The Basque Government established its own network and promoted the 'Age-Friendly' strategy in 2012, with its development fostered by a third sector organisation (Matia Foundation $^{3}$ ). Since then, sixty-five municipalities have joined the regional network, twenty-four from Gipuzkoa, twenty-four from Bizkaia, and seventeen from Araba ${ }^{4}(2019$ figures). Apart from the three main capital cities, even small villages have become involved in the network. Indeed, villages with no more than 1,000 inhabitants are also participating, and whilst they are not the focus of the present study, the development and performance of the age-friendly policies and strategies in such contexts could be of great interest for further research. Overall, the role of the Basque network is to provide information and support for new municipalities to join the network, and to support existing members. One of the activities includes the development of territorial committees bringing together different actors and stakeholders from each county and community involved in the network.

\section{Co-creation and co-production as key tools for the development of age-friendly strategies}

Co-creation and co-production approaches are becoming more and more relevant as welfare states in Europe are increasingly searching for new ways to organise welfare 
schemes (Burgess and Durrant, 2019; Pestoff, 2011) and community care at a neighbourhood level. In addition, because the AFCC initiative puts the focus on the promotion of participation and involvement of older people (Del Barrio et al., 2018) such approaches are also gaining relevance within age-friendly strategies. As both concepts have similar features but are in fact different practices, some clarification is needed in order to understand their role in Age-friendly strategies.

In the field of social policy, co-production has been linked to the involvement of users in the provision or implementation of a certain policy or service, once these have already been defined (Pestoff, 2011). Co-production can also take place in different phases, from design to management, implementation or evaluation (Brandsen and Honingh, 2015; Bovaird, 2007). Both approaches are the example of the existence of two main perspectives in this field. According to Flemig and Osborne (2019), the first relates to the traditional public administration view of co-production as a voluntary process extrinsic to statutory service encounters; and the second one, to the service management theory view, which conceptualises co-production as an intrinsic and often involuntary element of any service delivery encounter.

Co-creation is understood as a process by which two or more parties collaborate, or participate, in creating value for themselves or others (Hughes, 2014). Therefore, co-creation is not a mere platform for channelling people's views (Poocharoen and Ting, 2015), but a direct participation mechanism which allows public institutions to benefit from the knowledge and experience of individuals, groups, associations or other institutions. In both cases there is a relationship between a salaried employee of an organisation on the one hand and people or groups of citizens on the other (Brandsen and Honingh, 2015). But while co-production implies a process where the logic is linear and based upon product-dominant conceptions of production, co-creation is built upon an interactive and dynamic relationship where value is created at the nexus of interaction (Osborne, 2018). What this means is that, in general terms, co-creation processes could be seen as more 'open' and less predictable than traditional co-production methods, as the outcome depends on the interaction of the different parts involved. Although it is evident that both create value, the main difference could be concerning how participation is understood. Whereas co-production usually implies a narrower interpretation of the concept, as it relates mainly to the delivery of a service or the implementation of a policy, co-creation represents a wider paradigm, promoting participation in every stage of the policy-making process.

As Littlechild et al. (2015) have pointed out, co-creation and co-production processes with older people have developed more gradually than with other age groups. Nonetheless, the available literature and research indicates the value of these methods as they not only benefit the participant personally but also the communities in which they live (Beebeejaun et al., 2014; Bell and Pahl, 2018; Buffel, 2018a; Ward et al., 2018), as well as the public performance. In other words, they have an immediate social impact, and have the capacity to make policies and practices more responsive to the needs and demands of those involved.

In accordance with Buffel et al. (2019), the case for co-production and co-research (to which we could also add co-creation) with older people in developing age-friendly cities and communities is threefold. First, the approach represents a viable method for working with older residents and mobilising their expertise. Second, it gives older people themselves a key role to play in the creation and development of policies and agefriendly initiatives. Third, it offers a range of benefits to the different stakeholders involved, 
in that it provides a forum for rich and meaningful social engagement, and mutual learning and exchange. However, as Hafford-Letchfield (2019) argues, there is no solid evidence on what works best to achieve participation and co-production with older people.

Based on previous literature, this author (Hafford-Letchfield, 2019) highlights four challenges that must be addressed at a time when debates are rife about the future, purpose and role of public services. Following this author, these comprise: 1) embedding co-production within commissioning activity; 2) generating evidence of the value of co-production; 3) scaling up successful approaches from local initiatives; and 4) developing the skills of professionals on 'how to do it'. Our article will focus on contributing to the two last points - that is, learning from different local initiatives and identifying key elements about how to proceed.

\section{A glimpse into the socio-political reality of the Basque Autonomous Region}

The Basque Autonomous Region (BAR) is one of the seventeen autonomous regions in Spain and has three provinces: Bizkaia, Gipuzkoa and Araba. Their respective capital cities are Bilbao, Donostia/San Sebastián and Vitoria/Gasteiz. BAR has a population of 2,180,449 million (2018), with 342,810 in Bilbao, 243,815 in Vitoria/Gasteiz, and 180,989 in Donostia/San Sebastián (EUSTAT, 2019) ${ }^{5}$. These cities represent 35 per cent of BAR's population, but if we include the urban conurbations around them, this percentage reaches 66.2 per cent of the region's population. Therefore, the Basque society can be characterized as largely urban, with cities formed by high-density housing areas, especially in the case of Bilbao. Historically, BAR has been one of the most industrialised areas in Spain, with Bilbao as the main industrial area and seaport. However, following the general tendency across Europe, industrial and manufacturing production has declined, and the service sector has become more relevant. According to data provided by INE (2017) ${ }^{6}$, BAR is one of the wealthiest regions in Spain, with GDP per capita 31.5 per cent points above the average for the country. Furthermore, its average annual income per inhabitant is the highest at national level, being $€ 15,300$ in the Basque region compared to $€ 11,680$ in Spain (INE, 2019), while the average unemployment rate in the region stands at 8.7 per cent in comparison to 14.45 per cent in Spain as a whole (INE, 2020).

In terms of administrative structure, the Spanish political system is more similar to a federal than a centralised state, and each region has competences to develop its own health, education, and social service systems. Only social security is controlled directly by the central government. Additionally, BAR has a higher level of self-governance, in comparison to other regions, which leads to, in the opinion of some authors, an internal federal configuration (Arrieta, 2019; Novo, 2010). The main difference with other regions is that BAR has a taxing power that is unique in that it has the right to collect taxes via what is known as 'cupo', which is an arrangement between central and regional governments.

\section{The ageing process in the three capital cities of the Basque Autonomous Region}

Throughout the last decades, the demographic dynamics of BAR and its main capital cities have been characterised by a slight variation in the total number of residents but a profound change in the age structure of the population. The percentage of the population 
Table 1 Ageing percentages in the three cities, BAR and Spain (2018)

\begin{tabular}{lccccc}
\hline \hline & Bilbao & $\begin{array}{c}\text { Donostia/San } \\
\text { Sebastián }\end{array}$ & $\begin{array}{c}\text { Vitoria- } \\
\text { Gasteiz }\end{array}$ & BAR & Spain \\
\hline $\begin{array}{l}\text { Population } \\
\begin{array}{l}\text { People aged 65 and } \\
\text { over (\%) }\end{array}\end{array}$ & 342.810 & 180.989 & 243.815 & 2.180 .449 & 46.658 .447 \\
$\begin{array}{l}\text { People aged 75 and } \\
\text { over (\%) }\end{array}$ & 12.97 & 11.72 & 9.74 & 11.8 & 9.51 \\
\hline \hline
\end{tabular}

Source: Compilation based on the data obtained from INE [2019] and EUSTAT [2019]

aged sixty-five and over shows that the Basque region is undergoing a significant ageing process. According to EUSTAT (2019), the percentage for the region is 22 per cent, which is similar to the percentage in Vitoria-Gasteiz (21 per cent) and even higher in Bilbao (24 per cent), and Donostia/San Sebastián (24 per cent). For those aged seventy-five and above, the figures are 9.74 per cent in Vitoria-Gasteiz, 12.97 per cent in Bilbao, and 11.72 per cent in Donostia/San Sebastián (see Table 1).

This also raises the demand for services of different kinds, and particular issues linked to the increased diversity within the ageing population. As the profiles of older people are becoming more diverse, the needs and demands of this age group are also changing. Examples include changes in social and family structures (job conditions, single and single parent households, ageing migrants, etc), and the different lifestyles that these new older generations have experienced compared with younger cohorts (baby boomers) (Del Barrio et al., 2018).

In terms of the structure of families or households, the greatest change in relation to the capacity of families for caring has occurred with the progressive incorporation of women into the labour market. This has undermined the gender-specific division of labour based around the 'male breadwinner' model, with women relegated to domestic and care work. In the case of the Spanish and Basque societies, with a welfare model dependent upon the central role of families as carers, a 'care crisis' (Pérez Orozco, 2006) is taking place. Furthermore, while women have 'masculinized' their careers, men have not 'feminized' theirs in the same way (Esping-Andersen and Palier, 2011); most of the household burden still falls upon women. This reality could be applied to informal care in general (Carrasco, 2013; De los Santos et al., 2012), or specifically to the care of elderly relatives (Comas-d'Argemir, 2015).

\section{Methodology}

The present study aims to analyse age-friendly strategies in BAR by focusing on the challenges that arise from the development of co-creation and co-production processes. The research has been carried out in the three main capital cities of the region (Bilbao, Vitoria-Gasteiz and Donostia/San Sebastián). It has been guided by one main research question:

- What are the main challenges for the development of co-creation and co-production projects within age-friendly strategies? 
Table 2 Participants sample

\begin{tabular}{|c|c|c|c|}
\hline & Bilbao & $\begin{array}{l}\text { Donostia/San } \\
\text { Sebatián }\end{array}$ & Vitoria-Gasteiz \\
\hline $\begin{array}{l}\text { Participants (n) } \\
\text { Background } \\
\text { participants }\end{array}$ & $\begin{array}{l}\mathrm{n}=11 \\
\text { Politician }(\mathrm{n}=2) \\
\text { Public manager } \\
\quad(\mathrm{n}=2) \\
\text { Expert-Third Sector } \\
(\mathrm{n}=7)\end{array}$ & $\begin{array}{l}\mathrm{n}=11 \\
\text { Politician }(\mathrm{n}=1) \\
\text { Public manager } \\
\quad(\mathrm{n}=3) \\
\text { Expert-Third Sector } \\
(\mathrm{n}=7)\end{array}$ & $\begin{array}{l}\mathrm{n}=5 \\
\text { Politician }(\mathrm{n}=1) \\
\text { Public manager } \\
\quad(\mathrm{n}=4)\end{array}$ \\
\hline
\end{tabular}

The research question has been posed in an open and general way in order to cover a wide range of topics related to the different challenges that may arise from this type of process, and also to tackle some of the knowledge gaps found in the field of AFCC. The cities were purposefully selected on the basis that they: (1) had adopted the WHO framework so as to structure their work around age-friendliness; (2) were amongst the first to become members of the GNAFCC in Spain, reflecting their pioneering role in developing age-friendly programmes; and (3) were the capital cities of the three different provinces.

The research followed a qualitative methodology in which an in-depth interview technique was applied. A total of twenty-seven interviews were conducted, using a semistructured qualitative questionnaire. A semi-structured approach was chosen because of the extensive knowledge the interviewees had in the field, allowing us to learn about new aspects and for the participants to put forward new ideas. Given that they were experts and had in-depth knowledge of the topics covered, this technique was considered to be the most suitable to meet the needs of the research, as it provided a framework where the people interviewed could contribute a large amount of information. Questions included a focus on Age Friendly strategies, co-production initiatives, and barriers, difficulties or challenges for their development.

\section{Sampling and recruitment strategy}

This study used a purposive sampling strategy (see Table 2). We recruited participants from different backgrounds with an interest in ageing policies in BAR, including politicians and policy makers, high-ranking public managers, experts and academics. Eighteen women and nine men participated in the study. Thirteen were from the public sector, and fourteen were scholars or experts. A similar number of public sector professionals were interviewed in each city (five in Vitoria-Gasteiz, four in Donostia- San Sebastian and four in Bilbao). Contact was established using the 'snowball' sampling technique, i.e. asking the interviewees about key informants, which led to another series of contacts and thus widened the range of people that could be reached.

\section{Data analysis}

The qualitative data was transcribed and examined through category analysis methods using Atlas.ti8 software. The data was analysed using an 'open' coding and inductive 
strategy by which it was coded, sorted and sifted. The analysis followed different steps: the first step involved highlighting important passages. In the second step, passages were compiled and assigned to each main category (Age-Friendly strategies, co-creation processes, and difficulties/challenges). These data was subsequently coded following an open coding strategy, identifying emergent topics and ideas. Subsequently, sub-categories were constructed, clustering and determining hierarchy among different codes (i.e. older people's associations < key stakeholders <participants). Finally, the results and findings were presented following a category-based analysis. It is worth highlighting, as Chowdhury (2015) points out, that conclusions were made on the basis not only of a robust methodology, but also of a sensitivity to the contexts and situations in which the research takes place.

\section{Findings}

In the following sections, the main findings are presented in two parts. The first part provides a brief description of three different co-production or co-creation initiatives identified in each city, to serve as examples, while the second unveils the main challenges facing the development of those initiatives.

\section{Identifying co-creation and co-production initiatives for the development of $A F$ strategies}

The analysis suggests that all three cities had developed either a co-creation or a co-production process as part of the development of their age-friendly strategies. An example of this is the project Mirada activa ('Active glance'), which is a co-production initiative in Bilbao. Starting in 2016, the project aimed to fight loneliness among older people, encouraging them to take part in the process by acting as 'aerials', which detect cases of loneliness. The methodology is based on recruiting older people, mostly active members in community organisations, who are given the task of reporting cases of loneliness or isolation to the social services. It is important to mention here that the project was promoted by the Social Action Department of Bilbao's city council, and the main allies in developing the strategy throughout the city were older people's associations, which are usually located in public venues across different neighbourhoods.

In the city of Donostia/San Sebastian (which was the first in Spain and one of the first in the world to join the GNAFCCC), the 'Lkaleak' project (see Zuniga et al., 2019) is an example of a co-creation process. In this process, older people from a neighbourhood (Egia) in the city, together with different institutions (public and private sector, the third sector, and the academic world), played a key role in creating community care policies for older adults in Donostia/San Sebastián. The project went through a series of three stages or 'waves', which took place in small groups. In each stage, work sessions were held with up to a maximum of seven people. In total, 117 people participated in different phases of the project. It should be highlighted that this project was developed in collaboration with Third Sector organisations and the University of Deusto.

Regarding the case of Vitoria-Gasteiz, the project 'Activa tu barrio' ('Activate your neighbourhood') is a co-production initiative whose aim is to promote more welcoming neighbourhoods, and to ensure that people can continue to carry out their daily activities and can interact and walk comfortably through the streets. The project has been set up in 
three different neighbourhoods, and is targeted at older people and residents, as well as businesses and associations. One of the project's activities has been to create 'safe routes' or safe pathways across the neighbourhoods, marked with signals that are located on streetlights, walls or benches and guide people towards meaningful landmarks across the neighbourhood.

In all three cases, age-friendly strategies had been promoted by the local authorities, with considerable support from the political sphere. While this may be seen as a positive, it also has some drawbacks. For example, when trying to set up projects in a local context, the fact that they were led by public institutions often meant they were interpreted as being developed from a top-down approach. This negatively impacted on the processes, resulting in challenges associated with the dissemination and involvement of professionals and citizens, who were often not aware about the project in its early stages:

We designed this diagnosis methodology and the action plan and then, when we evaluated the action plan, we realized that nobody believed in it... I mean, you set up a bunch of opinion groups, (...) and you come up with very cool ideas, which you put into a plan, but then this plan is not linked to the places where it has to be carried out. That is, the person who has influence, the technician who has influence or the department that has influence, even if they think it is good, they don't feel that it is something of their own, do they? (Public manager)

Furthermore, the only process of the three that has been defined as a co-creation process does appear to have obtained more positive results with regard to participation and impact at the institutional level. This may be due to the fact that this approach requires more intensive work, i.e. greater involvement and investment of resources, but also because the process of sharing reflections, which has not taken place in the co-production processes presented here, has a greater capacity for transformation.

\section{Unveiling the main challenges for the development of co-creation and co-production initiatives within AFCC strategies}

Before analysing the main challenges, it should be noted that the interviewees pointed out that there was a pressing need to move towards participatory and collaborative management models in order to effectively develop age-friendly and ageing strategies and policies. The current social and political context, featured by an increase in the demand of care and support for older people, combined with the decreasing capacity of public administration due to neoliberal policies and budgetary cuts (Moreno, 2012; Pavolini et al., 2015), has accelerated this need but also made it more challenging.

It is now becoming more and more evident that the public services that we designed are not capable of responding to complex problems. This is an important debate today in the public sector... that the current public services have not been designed to respond to the needs and demands arising from complex issues. (Expert)

These forms of participation are the ones that are really going to achieve something interesting for the community. And we must keep on working like this because the other ways, the institutional, formal, and rigid structures, no longer work. (Public manager) 
Co-creation and co-production were identified as relevant and necessary strategies, because they provide a response to the search for new ways of structuring the welfare mix by building upon the collaboration between different sectors involved in the provision of welfare and care (public sector, market, third sector, voluntary and community sector). But, whilst the general assessment of the co-creation or co-production processes was positive, common difficulties and challenges have also been found. Broadly speaking, these challenges could be divided into two main topics: how to promote effective participation and guaranteeing sustainability.

In general terms, putting participatory and collaborative governance processes in place is always seen as challenging, but it seems to be especially difficult to engage certain groups of people, such as frail or otherwise excluded older people. In the same vein, the achievement of intergenerational projects was indicated as highly desirable, but difficult to accomplish. In other words, the engagement of both adults and young people in the age-friendly initiatives is proving to be complex. A widespread strategy in BAR is to remove the term 'age' from the friendliness initiatives and try to guide them towards a friendliness that is understood as valuable for everyone. An expert explained this as follows:

One thing that we did in Lagunkoia, for example, was to take out the words '(for) elderly people'. Because if you say that a project is for elderly people, you will never achieve intergenerationality, unless you force it. (Expert)

Furthermore, the interviewees highlighted a range of difficulties in engaging various groups of older people in the different projects. Involving the most vulnerable older people, those defined as 'hard to reach' (Buffel, 2015; Craig, 2004), was seen as particularly difficult, especially the 'Oldest Old' (residents aged eighty-five-plus), who are at greater risk of social exclusion (Key and Culliney, 2018). Nonetheless, it should be stressed that although age could exacerbate certain exclusion factors like poverty, social isolation or health condition, it does not necessarily imply being vulnerable. As one of the interviewees stated, "we do know how to engage with the elite" (referring to the people with healthy and wealthy conditions) but not with the most vulnerable members of society.

I think we do know how to make the elite participate (...) and we can reach people who are already sensitised and motivated... but with the most vulnerable we have not found the way... we do not know how to connect with them, which channels to use, which topics to use to... [engage them]. (Public Manager)

Additionally, a certain resistance or reluctance to participate was noticed when the level of involvement or participation was not specified in the project description. In other words, not knowing how much time and effort would be needed to take part in a process can act as a barrier to participate. In contrast, it was pointed out that participation in specific activities, with well-scheduled processes, are considered more attractive and successful. Furthermore, having common interests was identified as promoting medium or long-term commitment. This suggests that co-creation or co-production processes ideally start from developing a shared diagnosis or design at the start of a project. As has often 
been argued by the interviewees, participatory processes promoted by public institutions respond more to the needs of the administration itself rather than to the necessities of older people and communities. In this regard, special emphasis has been placed on the fact that there is indeed a risk of Tokenism, and even 'exploitation' (Selloni, 2017), by promoting participation merely as a political strategy.

And there are so many things taking place, because nowadays it seems that everyone wants to do something with older people, right? (...) But we also have to be aware of saturation, and careful not to break people's trust (Expert).

The first step, therefore, will be to carry out a participatory process that allows a joint identification of the issues on which the process will focus. Thus, for co-production processes to be effective, participants should become involved in the initial design phase, and not only in the evaluation and implementation phases:

The way to empower people is by making them participate, from the beginning to the end. (Public manager)

But if there's a common interest that brings us together at the same table, then age is not an issue. In my opinion that's the path we must follow, and that's the way to beat [age-related] stereotypes, which, as you know, are a scourge.' (Expert)

Another issue in the debate is how to ensure the sustainability or continuity of co-production or co-creation processes, and what role public administration should play in achieving this. In many cases, community-based projects aim to activate networks and relationships that can continue to function autonomously, without the public administration intervening. Yet the experiences accounted for here suggest that continuity may be difficult to achieve without the monitoring or 'surveillance' of the administration. An expert commented:

A process can take many months to be set in motion, but if you do not keep working on it, then things will go back to how they were (...) Maybe there will come a time when it will evolve naturally and it will end up being built without having to supervise it. (Expert)

One measure that could be implemented to facilitate sustainability and continuity is to take a cross-sectorial approach in developing age-friendly projects and activities. This suggests a collaborative, inter-departmental approach, involving local authorities, and professional stakeholders from a range of backgrounds, as well as community organisations and citizens. However, the reality is that, except for one of the cities (Donostia-San Sebastián), where an inter-departmental approach was developed, most age-friendly strategies in BAR have been established by the Social Service department with limited input from other departments.

On the other hand, the importance or the value that individual leadership has in ensuring the success of projects has been repeatedly highlighted. The significance of leadership has been pointed out both in the institutional sphere, referring to the professionals involved, and at the community or citizen level, in reference to people with a special relevance or charisma in their organisations, communities or neighbourhoods. 
This issue must be taken into account, as the whole process can break down when a particular leader stops participating. This is especially relevant when working with older people, as for many different reasons, sometimes related to health conditions, these people are sometimes no longer able or willing to participate.

[About] the volunteering issue... One of the problems we have in 'Euskadi Lagunkoia', for example, is that there are very powerful promotional groups, as they are made up of very influential people, otherwise these groups wouldn't be so powerful. But because these people are elderly, they tend to get sick and then the whole group disintegrates. And then, in this sense, the 'friendliness' project can come to a halt. (Public manager)

Finally, loneliness was one of the main and recurring themes in the discourse about friendliness and ageing. It was suggested that the processes of co-creation and coproduction can have a particularly relevant role in addressing this issue. In addition to the fact that being involved in a participatory project can be beneficial for individuals in establishing social relationships, the result or outcome of such processes can also help to tackle loneliness at a community level. The observation that public institutions cannot sufficiently meet the social and affective needs experienced by individuals has led to the belief that communities and the voluntary sector have a crucial role to play. By concentrating their attention on this particular issue, processes are more likely to be sustained over time as communities and the voluntary sector can respond to a need that public institutions find difficult to meet.

What it [referring to a co-production project] does is try to give a different answer to the problem of loneliness, which is something that people are concerned about. Everybody worries about it, but no one knows how to reach the older people who live alone. (...) So it is something that causes concern in the city and every professional worries about it too. It is also a concern for neighbourhood associations, as well as businesses. (Public manager).

\section{Discussion}

The number of cities and towns developing AFCC strategies in BAR, and the creation of a regional network, shows that developing age-friendly environments has become a shared concern at a political level. However, the extent to which these strategies have been implemented at the local level and supported by professionals and citizens differs significantly. The rapid success and expansion of the AFCC initiative in BAR therefore carries the risk of becoming a slogan or tagline without demonstrable achievements.

Collaborative and participatory initiatives such as co-creation and co-production processes are considered essential for the development of age-friendly strategies, but our analysis has shown that they are far from common and systematised in the way they are developed. The analysed initiatives represent innovative projects within different institutions and require a new form of governance. Their small size as well as limited impact confirms their experimental status and, as discussed in the analysis, these strategies are not embedded in most departments within local authorities. As highlighted by McDonald et al. (2019) and which we also found to be true, age-friendly strategies have successfully mobilised political support, but older people's effective engagement in the programmes is more problematic. While co-production is said to be 'a good thing,' sharing 
power and control remains challenging, and more evidence is required on its outcomes (Hafford-Letchfield, 2019).

Our research suggests that political involvement, even if necessary, is meaningless if the strategy is not embedded in the work of influential stakeholders, especially those community-based organisations capable of developing strategies in local contexts. As Scharlach et al. (2014) pointed out, and this study confirmed, inconsistent plan implementation and lack of community structures which facilitate the translation of planning reports into ground-level actions are two of the most challenging issues when implementing community-wide planning strategies. Following Duran (2017), our analysis suggests that while bureaucracy is essential as a conveyor belt, the implementation of innovative plans can cause frictions, especially when there is a lack of responsible management and qualified or skilled professionals.

The study further shows that reaching out to the most vulnerable or excluded older people is considered to be one of the most important challenges in co-production or co-creation processes. As Buffel and Phillipson (2016) argue, the success of communities in becoming more age friendly will, to a large extent, depend on whether older people, including those facing social exclusion, become involved as key actors in future research and policies around age-friendly developments. As Smetcoren et al. (2019) point out, it takes a great deal of time to develop the necessary trust, network and relationships, and this time is not always available, especially within exploratory or short timeframe projects. Moreover, there are shared concerns about the effect of the 'care crisis' for older carers, especially among women, and its effects on social and civic participation. In order to increase the likelihood that people will participate and engage in age-friendly initiatives, the development of activities that require short-term commitments, with clearly defined goals and ambitions, will be important. Nevertheless, the participation of those in vulnerable situations or those who are main carers will remain a complex task as this is influenced by the conditions established by welfare and care systems.

Related to this point, the achievement of intergenerational projects (i.e. the participation of people from different age groups in the same process) has also been identified as a common struggle. There is clearly a need to develop ways in which younger generations can become involved in creating initiatives to help both present and future generations of frail and active older people alike. As Bovaird et al. (2015) argue, more imaginative and attractive ways will need to be found to convince a higher proportion of citizens to re-orient co-production activities towards more collective action. In this sense, the search for shared interests that appeal to all members of a community has been referred to as a possible alternative. That means that co-creation and co-production processes should start from the design stage, rather than when the aims and objectives have already been defined. In order to achieve sustainability and continuity, there is also a need to embed such initiatives in professional and stakeholders' networks (especially from the community sector), as well as a need for a long-term commitment from the administration, and a crosssectorial and inter-professional approach. Lawler (2015) suggests that the extraordinary breadth of the AFCC agenda could be paralysed with the development of short-term programmes or projects. Even if that affirmation could also be applied to the situation of $B A R$, the value of those small projects should be acknowledged, and finding a middle ground may be the way to achieve success.

Finally, as argued throughout this article the idea of achieving 'friendliness' within communities should be understood as a strategy for all ages (Lawler, 2015). Rather than 
defining 'age friendly' as a new programme or a trend in service delivery, this study suggests that it should be seen as an opportunity to re-think the way in which we live together.

\section{Acknowledgements}

We are very grateful to Christopher Phillipson, who offered his time and knowledge to help improve this article. The work by Dr. Tine Buffel was supported by the Leverhulme Trust (RL-2019-011) and by the Economic and Social Research Council (ESRC) under the Future Research Leaders scheme (ES/N002180/1).

\section{Notes}

1 Data obtained from the WHO website. https://extranet.who.int/agefriendlyworld/who-network/ (Accessed, 01.17.2020)

2 Data obtained from the IMSERSO website (Available at: http://www.ciudadesamigables.imserso. es/ccaa_01/ayun_parti/redespana/index.htm. (Accessed, 01.17.2020)

3 Non-for-profit institution specialised in the provision of care and welfare services for older people.

4 Data obtained from the Basque Age-friendly network website. (Available at: https://euskadilagun koia.net/es/municipios/municipios-amigables. Accessed, 01.17.2020)

5 Basque Statistics Institute (http://www.eustat.eus/indice.html)

6 Spanish Statistics Institute (https://www.ine.es/)

\section{References}

Arrieta, F. (2019) El Archipiélago del Bienestar: El Sistema de Servicios Sociales en el País Vasco, Madrid: Catarata.

Beebeejaun, Y., Durose, C., Rees, J., Richardson, J. and Richardson, L. (2014) “Beyond text': exploring ethos and method in co-producing research with communities', Community Development Journal, 49, 1, 37-53.

Bell, D. and Pahl, K. (2018) 'Co-production: towards a utopian approach', International Journal of Social Research Methodology, 21, 1, 105-117.

Bovaird, T. (2007) 'Beyond engagement and participation: user and community coproduction of public services', Public Administration Review, 67, 5, 846-860.

Bovaird, T., van Ryzin, G., Loeffler, E. and Parrado, S. (2015) 'Activating citizens to participate in collective co-production of public services', Journal of Social Policy, 44, 1, 1-23.

Brandsen, T. and Honingh, M. (2015) 'Distinguishing different types of coproduction: a conceptual analysis based on the classical definitions', Public Administration Review, 76, 427-435.

Buffel, T. (ed.) (2015) Researching Age-Friendly Communities. Stories from Older People as Co-Investigators, Manchester: The University of Manchester Library.

Buffel, T. and Phillipson, C. (2016) 'Can global cities be 'age-friendly cities'? Urban development and ageing populations', Cities, 55, 94-100.

Buffel, T. (2018a) 'Older coresearchers exploring age-friendly communities: an 'insider' perspective on the benefits and challenges of peer-research', The Gerontologist, 59, 3, 1-11.

Buffel, T. (2018b) 'Social research and co-production with older people: developing age-friendly communities', Journal of Aging Studies, 44, 52-60.

Buffel, T., Handler, S. and Phillipson, C. (2018) Age-Friendly Cities and Communities: A Global Perspective, Bristol: Policy Press. 
Buffel, T., Phillipson, C. and Rémillard-Boilard, S. (2019) 'Age-friendly cities and communities: new directions for research and policy', in D. Gu and M. Dupre (eds.), Encyclopedia of Gerontology and Population Aging, Cham: Springer.

Burgess, G. and Durrant, D. (2019) 'Reciprocity in the co-production of public services: the role of volunteering through community time exchange', Social Policy and Society, 18, 2, 171-186. doi: $10.1017 / S 1474746418000076$.

Carrasco, C. (2013) 'El cuidado como eje vertebrador de una nueva economía', Cuadernos de Relaciones Laborales, 31, 1, 39-56.

Chowdhury, M. F. (2015) 'Coding, sorting and sifting of qualitative data analysis: debates and discussion', Quality and Quantity, 49, 1135-1143.

Comas-d'Argemir, D. (2015) 'Los cuidados de larga duración y el cuarto pilar del sistema de bienestar', Revista de Antropología Social, 24, 375-404.

Craig, G. (2004) 'Citizenship, exclusion and older people', Journal of Social Policy, 33, 1, 95-114.

De los Santos, A., Perla, V., y Valdés, C. and Emma, S. (2012) 'Cuidado informal: una mirada desde la perspectiva de género', Revista Latinoamericana de Estudios de Familia, 4, 138-146.

Del Barrio, E., Marsillas, S., Buffel, T., Smetcoren, A. and Sancho, M. (2018) 'From active aging to active citizenship: the role of (age) friendliness', Social Sciences, 7, 8, 134.

Doran, P. and Buffel, T. (2018) 'Translating research into action: involving older people in co-producing knowledge about age-friendly neighbourhood interventions', Working with Older People, 22, 1, 39-47.

Duran, M. (2017) 'Ciudades que cuidan', in M. Nieves and O. Segovia (eds.), ¿Quién Cuida en la Ciudad? Aportes Para Políticas Urbanas de Igualdad, Santiago de Chile: CEPAL, 91-116.

Esping-Andersen, G. and Palier, B. (2011) Los Tres Grandes Retos del Estado de Bienestar, Barcelona: Ariel.

EUSTAT (2019) Indicadores Demográficos 2017, Nota de prensa 05/04/2019, Donostia/San Sebastián, https://www.eustat.eus/elementos/ele0016300/continua-aumentando-la-esperanza-de-vida-de-hombresy-mujeres-en-la-c-a/not0016390_c.html [accessed 05.26.2021].

Flemig, S. and Osborne, S. (2019) 'The dynamics of co-production in the context of social care personalisation: testing theory and practice in a Scottish context', Journal of Social Policy, 48, 4, 671-697.

Hafford-Letchfield, T. (2019) 'Participation and co-production in the care and support of older people', in D. Gu and M. Dupre (eds.), Encyclopedia of Gerontology and Population Aging, Cham: Springer. doi: 10.1007/978-3-319-69892-2_369-1.

Hughes, T. (2014) 'Co-creation: moving towards a framework for creating innovation in the triple helix', Prometheus, 32, 4, 337-350. doi: 10.1080/08109028.2014.971613.

INE (2017) Data obtained from Spanish Statistics Institute website, https://www.ine.es/dyngs/INEbase/ es/operacion.htm?c=Estadistica_C\&cid=1254736167628\&menu=ultiDatos\&idp=1254735576581 [accessed 01.17.2020].

INE (2019) Data obtained from Spanish Statistics Institute website, https://www.ine.es/jaxiT3/Datos.htm?t= 9947 [accessed 01.17.2020].

INE (2020) Data obtained from Spanish Statistics Institute website. Encuesta de población activa 2020, https://www.ine.es/dyngs/INEbase/es/operacion.htm?c=Estadistica_C\&cid=1254736176918\&menu= ultiDatos\&idp=1254735976595 [accessed 01.17.2020].

Kano, M., Rosenberg, P. and Dalton, S. (2018) 'A global pilot study of age-friendly city indicators', Social Indicators Research, 138, 1205-1227.

Key, W. and Culliney, M. (2018) 'The oldest old and the risk of social exclusion', Social Policy and Society, $17,1,47-63$.

Lawler, K. (2015) 'Age-friendly communities: go big or go home', Public Policy and Aging Report, 25, 30-33.

Littlechild, R., Tanner, D. and Hall, K. (2015) 'Co-research with older people: perspectives on impact', Qualitative Social Work, 14, 1, 18-35. 
McDonald, B., Scharf, T. and Walsh, K. (2019) 'Creating an age-friendly county in Ireland: stakeholders' perspectives on implementation', in T. Buffel, S. Handler and C. Phillipson (eds.), Age Friendly Cities and Communities. A Global Perspective, Bristol: Policy Press, 143-166.

Moreno, L. (2012) La Europa Asocial, Barcelona: Ediciones Península.

Moulaert, T. and Garon, S. (eds.) (2016) Age-Friendly Cities and Communities in International Comparison, Cham: Springer.

Nieboer, A. and Cramm, J. (2018) 'Age-friendly communities matter for older people's well-being', Journal of Happiness Studies, 19, 2405-2420.

Novo, A. (2010) La Excepcionalidad del Modelo Federal Foral Vasco, Valencia: Tirant lo Blanch.

Osborne, S. (2018) 'From public service-dominant logic to public service logic: are public service organizations capable of co-production and value co-creation?', Public Management Review 20, 2, 225-231.

Pavolini, E., León, M., Guillén, A. and Ascoli, U. (2015) 'From austerity to permanent strain? The EU and welfare state reform in Italy and Spain', Comparative European Politics, 13, 56-76

Pérez Orozco, A. (2006) 'Amenaza tormenta: la crisis de los cuidados y la reorganización del sistema económico', Revista de Economía Crítica, 5, 7-37.

Pestoff, V. (2011) 'Co-Produção, nova governança pública e serviços sociais no terceiro setor na Europa', Ciências Sociais Unisinos, 47, 1, 15-24.

Poocharoen, O. and Ting, B. (2015) 'Collaboration, co-production, networks: convergence of theories', Public Management Review 17, 4, 587-614.

Rémillard-Boilard, S. (2018) 'The UK network of age-friendly communities: a general review', Working with Older People, 22, 1, 30-38.

Scharlach, A., Davitt, J., Lehning, A.J., Greenfield, E.A. and Graham, C.L. (2014) 'Does the village model help to foster age-friendly communities?', Journal of Aging and Social Policy, 26, 1-2, 181-196.

Selloni, D. (2017) CoDesign for Public-Interest Services, Cham: Springer.

Smetcoren, A., De wonder, L., Duppen, D., De Witte, N., Vanmechelen, O. and Verté, D. (2019) 'Towards an "active caring community",' in T. Buffel, S. Handler and C. Phillipson (eds.), Age Friendly Cities and Communities. A Global Perspective, Bristol: Policy Press, 97-118.

Ward, P., Banks, S., Hart, A. and Pahl, K. (2018) 'Conclusion: imagining different communities and making them happen,' in S. Banks, A. Hart, K. Pahl and P. Ward (eds), Co-producing Research: A Community Development Approach, Bristol: Policy Press, 203-209.

WHO (2018) La Red Mundial de Ciudades y Comunidades Adaptadas a las Personas Mayores: Revisar El Último Decenio Y Mirar Con Optimismo Hacia El Siguiente, Ginebra: World Health Organization.

Zuniga, M., Salaberria, E. and Arrieta, F. (2019) 'An analysis of the role of communities in care systems co-created with older people', Public Management Review, 22, 12, 1799-1818. 